\title{
Invasive and potentially invasive plant species in State Nature Biosphere Reserves of the Altai Republic (Russia)
}

\author{
I. A. Artemovi,2*, E. Yu. Zykova' \\ ${ }^{1}$ Central Siberian Botanical Garden, Siberian Branch of the Russian Academy of Sciences \\ Novosibirsk, Russia \\ 2Katunskiy State Nature Biosphere Reserve \\ Ust'-Koksa, Altai Republic, Russia \\ E-mail:artemov1@mail.ru, elena.yu.zykova@gmail.com
}

\begin{abstract}
In the Altaiskiy and Katunskiy State Nature Biosphere Reserves we registered 44 alien plant species, which were considered in Siberia as invasive and potentially invasive. Among them, there were 30 xenophytes and 14 ergasiophytes species. Rumex acetosella L., Impatiens glandulifera Royle, Galinsoga ciliata (Rafin.) Blake, and Strophiostoma sparsiflorum (Mikan ex Pohl) Turcz. are considered invasive in the Altaiskiy Reserve because they actively spread there in natural and seminatural plant communities and habitats. Most of the species had appeared in the territories of the reserves before their establishment as a result of agricultural activity or appeared after their establishment because of activity of the reserves themselves. Despite of a big amount of tourists in the reserves, the invasive and potentially invasive plants are absent on the ecological paths at present.
\end{abstract}

Keywords: alien plant species; invasive plant species; Altaiskiy Reserve; Katunskiy Reserve; recreation

\section{Introduction}

Invasion of alien species is the global problem, which is strengthening in XXI century (Tittensor et al. 2014; Early et al. 2016). By now 14000 alien plant species are known, 13000 of which have already naturalized in at least one region of the world (van Kleunen et al., 2015, 2019). In $42 \%$ terrestrial regions of the world, the proportion of naturalized alien plant species is 10-40 \% and this number is increasing (Pyšek et al. 2017). Often naturalization of new species leads to declining of activity and reproduction ability of native ones, reduction of their ranges and, as a result, unification of biota and the loss of biodiversity (Williamson 1996; Alimov and Bogutskaya 2004; Olmstead 2006). Therefore naturalization of alien species in regions with a high level of endemism and biodiversity requires exceptional attention (Early et al. 2016), as well as in biosphere natural reserves, which are key elements of biodiversity and for which conservation of biodiversity is a principal task (Monaco and Genovesi 2014; Foxcroft et al. 2017).

The Altai Republic is situated in the Russian part of the Altai mountains and with other mountain regions of Southern Siberia and Northern Mongolia belongs to the Altai-Sayan Ecoregion, which was identified by WWF as one of 200 the most crucial territories to the conservation of global biodiversity (Olson and Dinerstein 2002). Over the last decades, ecosystems of the Altai Republic were undergoing substantial recreation pressure because of increase of the tourism activity. The number of tourists in the Altai Republic raised from less than 400 thousand in 2003 to more than 2 million in 2017 (Medvedeva 2018). Such a growth inevitably resulted in arriving of great number of alien plant species, some of which successfully naturalized. To date, the alien flora of the Altay Republic counts 230 vascular plant species (Zykova, 2015). Among them there are intensively spreading and harmful invasive ones: Acer negundo L., Centaurea jacea L., Conyza canadensis L., Echium vulgare L., Echynocistis lobata (Mich.) Torr. et Gray, Bunias orientalis L., Galega orientalis Lam., Heliantus tuberosus L., Heracleum sosnowskyi Manden., Hordeum jubatum L., Impatiens glandulifera Royle, Rorippa sylvestris (L.) Bess., and Solidago canadensis L. (Zykova 2016).

In the Altai Republic, there are two reserves of federal status: the Altaiskiy and Katunskiy State Nature Biosphere Reserves (Fig. 1), which were established in 1932 and 1991 respectively (Maleshin et al. 1999; Artemov et al 2000). The principal tasks of state reserves are protection of nature, research and ecological education. Any person may visit ranger stations and walk along ecological paths. In 2017 about 1700 people visited the Katunskiy Reserve and 54000 visitors were in the Altaiskiy Reserve. 


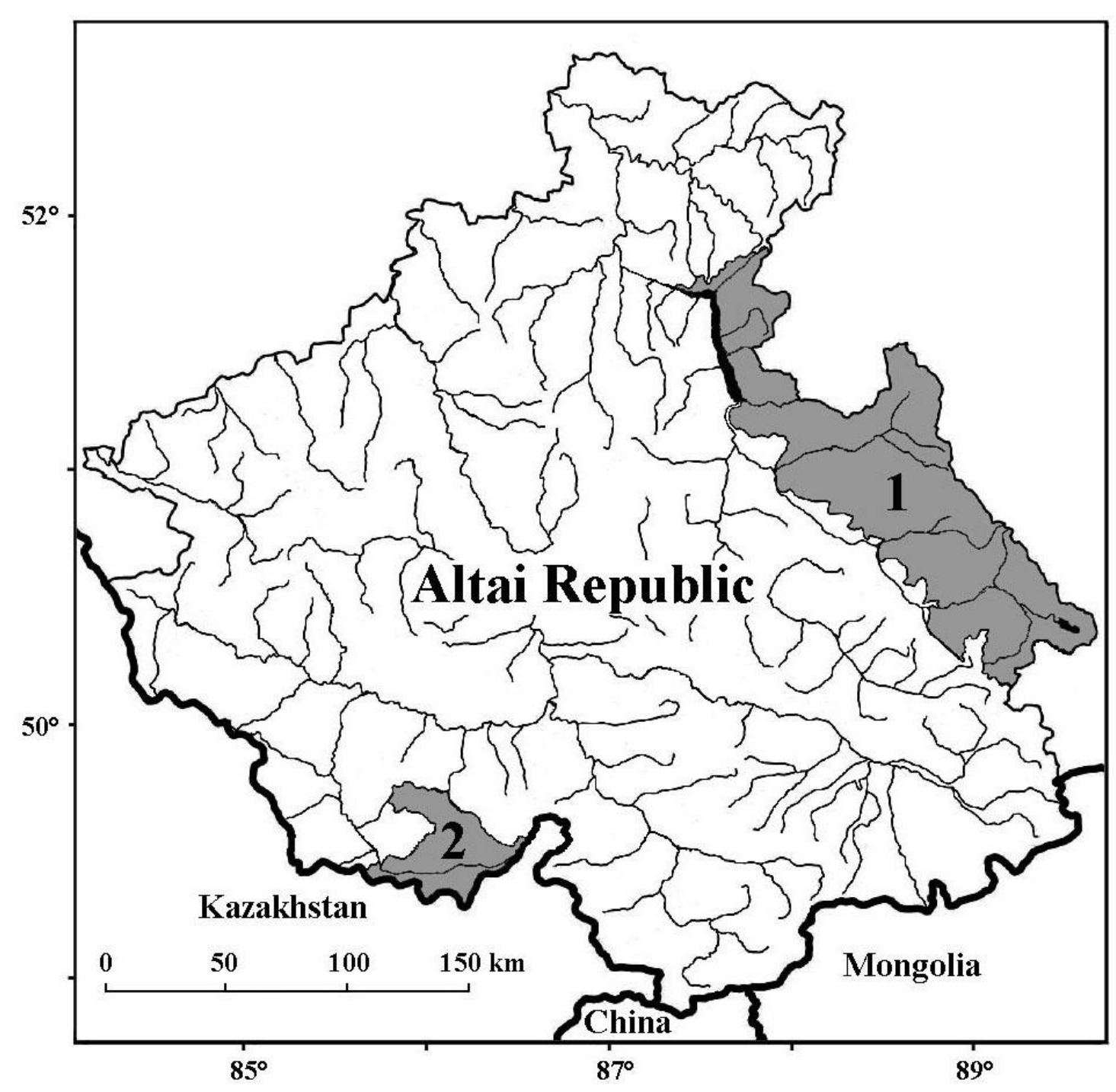

Fig. 1 State Nature Biosphere Reserves of the Altai Republic: 1 - Altaiskiy State Nature Biosphere Reserve, 2 - Katunskiy State Nature Biosphere Reserve

It is possible that ecological tourism causes introduction of alien species to the territories of the reserves. Indeed, a positive correlation among non-native plant species richness and the number of visitors as well as the total length of backcountry trails was revealed in 216 national parks in the United States (Allen et al. 2009). The success of naturalization depends on ecological factors such as climate and altitude. For example, in the Czech Republic, the proportion of alien species is less in nature reserves with high average altitude and more in reserves situated in warm climatic region (Pyšek et al. 2002). Besides, existence of alien species in reserves may be caused by the use of their territories before the reserves establishment, as well as after their establishment because of activity of the reserves themselves, in particular transport links and exploitation of certain areas as vegetable gardens, pastures and hayfields for internal needs of reserves (Nukhimovskaya 1986; Starodubtseva et al. 2017).

The purpose of the present work is to reveal invasive and potentially invasive plant species in the reserves of the Altai Republic, to define the way of their invasion and the level of naturalization.

\section{Material and methods}

The Altaiskiy Reserve is situated along the north-eastern border of the Altai Republic, in 50.27-51.93 N and 87.37$89.87 \mathrm{E}$. The elevation difference reaches more than $3000 \mathrm{~km}$ : from $434 \mathrm{M}$ (Lake Teletskoye) to $3504 \mathrm{~m}$ a.s.l. (Mountain Tashkaly-Kaya on the Shapshal'skiy Range). Area of the reserve is 881238 ha. The territory comprises the Korbu and the Kyrlygan Ranges, western and south-western principal slopes of the Shapshal'skiy and the Abakanskiy Ranges, the Chulyshmanskoe Upland, the eastern bank and part of waters of Lake Teletskoye. The climate in the reserve is continental, but the weather conditions in its lakeside north-western part is essentially softer than in its south-eastern part. In the lakeside zone, the average January temperature is $-8.7^{\circ} \mathrm{C}$, the average July temperature is $+16.0^{\circ} \mathrm{C}$, the annual precipitation is $850-1100 \mathrm{~mm}$, while in the south-east of the reserve, the winter and summer temperatures reach $-50^{\circ} \mathrm{C}$ and $+30^{\circ} \mathrm{C}$, respectively, and the annual precipitation is 3-4 times less. The low mountains and the mid-mountains of the reserve are 
mainly occupied by taiga ecosystems, in the high mountains are common subalpine, alpine, tundra, tundra-steppe and glacial-nival ecosystems. The flora of the reserve comprises 1500 species of vascular plants. The main anthropogenic pressure takes place on the lakeside part of the reserve where principal elements of its infrastructure are situated: Yaylyu village with the reserve administration; Karatash, Baygazan, Kokshi, Chelyush, Bele and Chiri ranger stations; tourist camps and ecological paths (Maleshin et al., 1999; Krever, 2012; Altaiskiy State Nature Biosphere Reserve, n.d.) (Fig. 2).

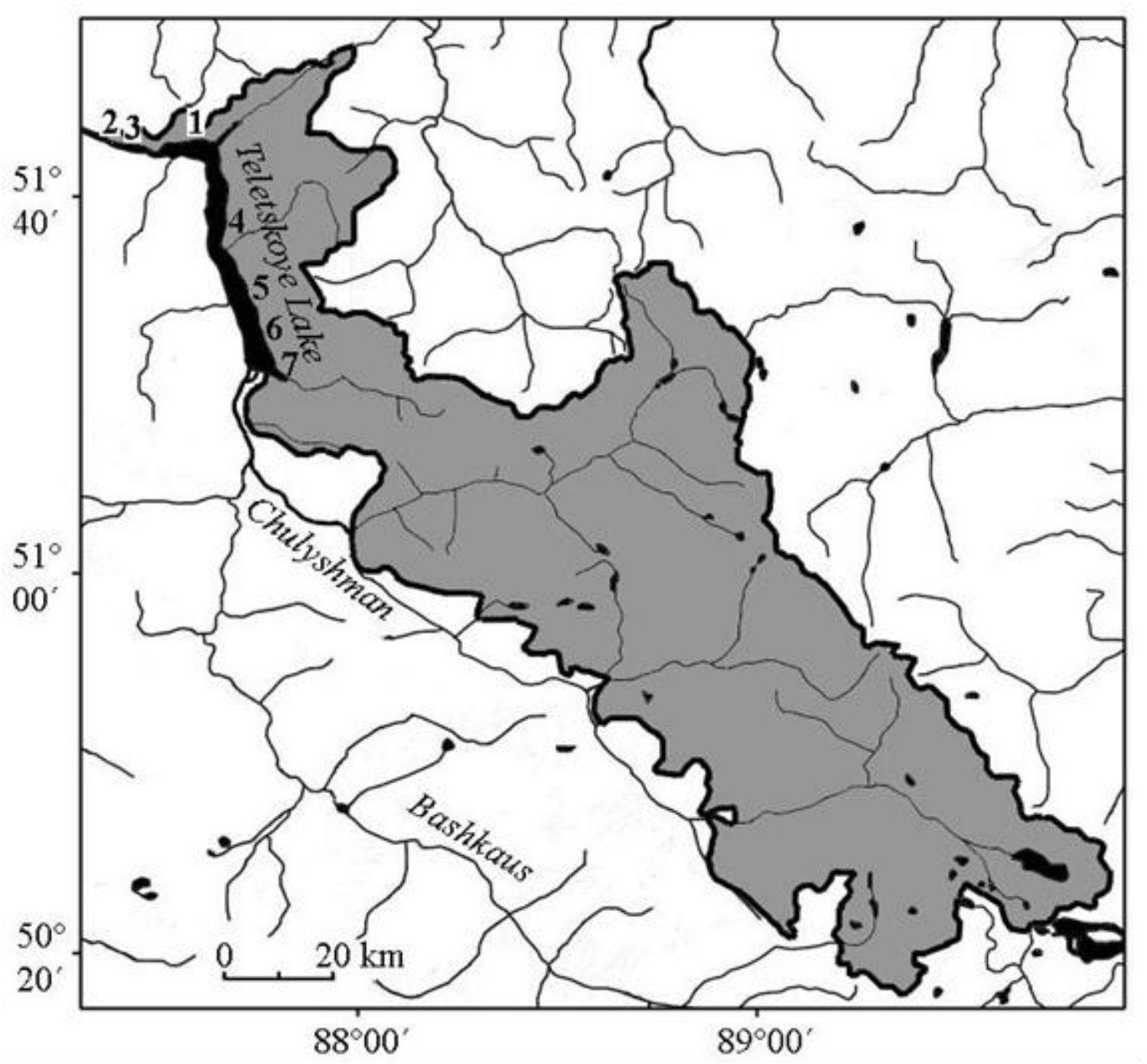

Fig. 2 Altaiskiy State Nature Biosphere Reserve: 1 - Yaylyu village; ranger stations: 2 - Karatash, 3 - Baygazan, 4 - Kokshi, 5 - Chelyush, 6 - Bele, 7 - Chiri

The Katunskiy Reserve is situated near the southern border of the Altai Republic, on the Katunskiy and Listvyaga Ranges, in 49.47-49.93 N and 85.62-86.57 E. The absolute altitudes in its territory vary from 1300 to $3280 \mathrm{~m}$ a.s.l. Area of the reserve is $151664 \mathrm{ha}$. In the valleys of the mid-mountains the average January temperatures are -18 to $-22^{\circ} \mathrm{C}$, in July these are +13 to $+15^{\circ} \mathrm{C}$, in high mountains the average January and July temperatures are -15 to $-17^{\circ} \mathrm{C}$ and +4 to $+6^{\circ} \mathrm{C}$, respectively. The main area of the reserve are occupied by taiga and meadow ecosystems of the forest, meadow-forest and subalpine vegetation belts.

The steppe ecosystems are poorly presented in the reserve because of relatively high base level of it. The flora of the reserve comprises about 670 species and subspecies of vascular plants. The permanently used ranger stations are located in the buffer zone, that reduces probability of alien species invasions into the core zone of the reserve. These are ones near the mouth of the Tikhaya River, Lakes Taymen'e and Srednee Mul'tinskoe. The ranger stations located in the core zone of the reserve serve for temporary stops of rangers during raids and of tourists during long routes. These are ones at the Zaychikha, Tyurgen' and Kazinikha Rivers. Some diurnal and multi-day routes are proposed for visitors of the reserve. Among the existing ranger stations and routes only the most accessible ranger station near Lake Srednee Mul'tinskoe and ecological paths in the Mul'tinskie lakes area undergo any substantial recreation pressure (Artemov et al. 2000; Artemov 2012; Katun Nature Reserve, n.d.) (Fig. 3). 


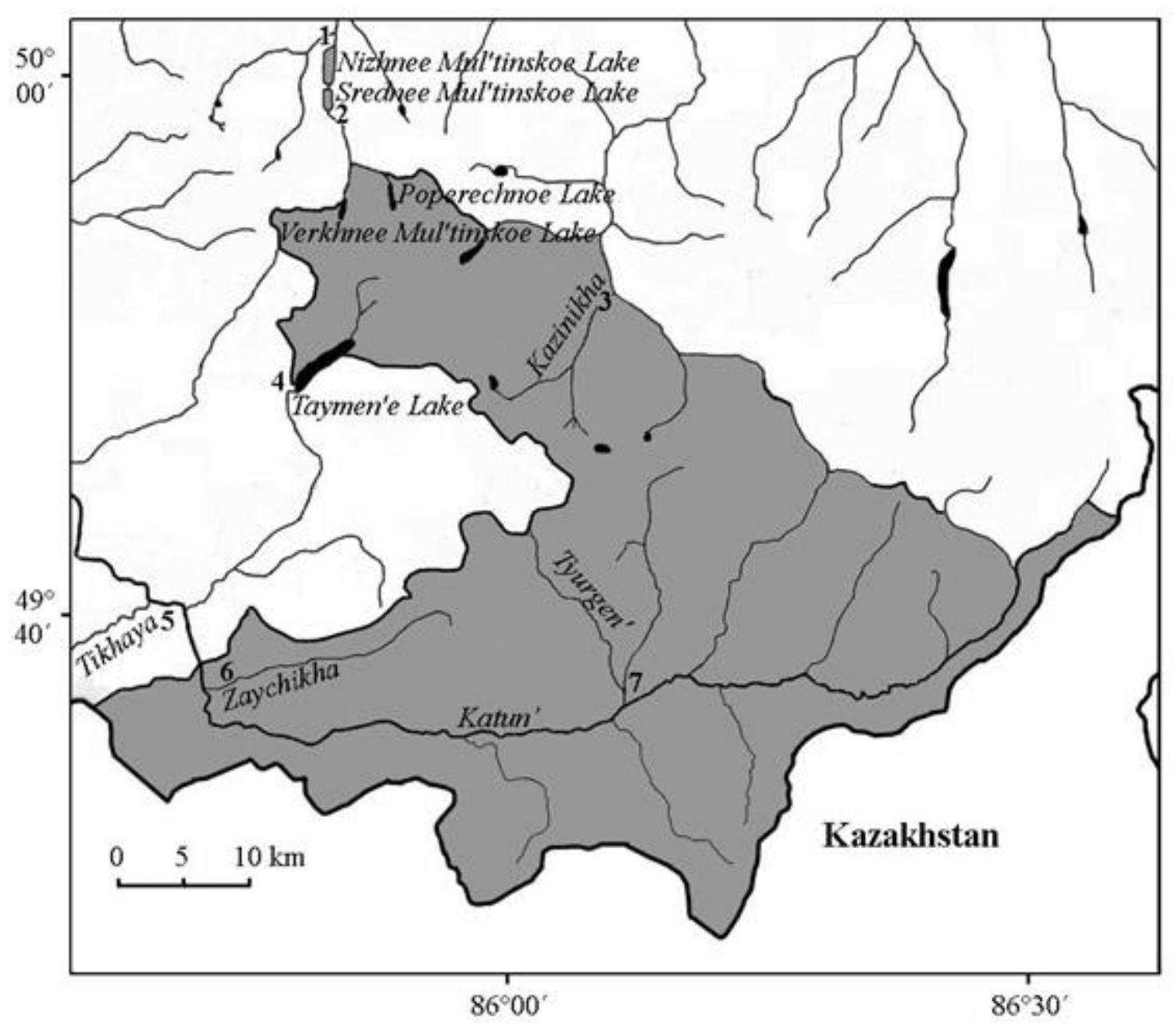

Fig. 3 Katunskiy State Nature Biosphere Reserve: tourist base and ranger stations in the buffer zone: 1 - tourist base near Nizhnee Mul'tinskoe Lake, 2 -Srednee Mul'tinskoe Lake, 4 -Taymen'e Lake, Tihaya River; ranger stations in the core zone: 3 - Kazinikha River, 6 - Zaychikha River, 7 - Tyurgen' River

Field research were conducted at Yaylyu village, Karatash, Baygazan, Kokshi, Chelyush, Bele, Chiri ranger stations, the path and the observation point near the Korbu Waterfall in the Altaiskiy Reserve and at the ranger station near Lake Srednee Mul'tinskoe in the Katinskiy Reserve in 2017-2018. The previosly published results of author's multiyear plant species inventory in the core zone of the Katunskiy Reserve near ranger stations at the Zaychikha, Tyurgen' and Kazinikha Rivers were considered as well (Artemov 2012). Collected specimens were delivered to the Herbarium of the Central Siberian Botanical Garden, SB RAS (NS).

Alien plants of the Altaiskiy and Katunskiy Reserves included in the list of invasive and potentially invasive species in Siberia (Ebel et al. 2014) were taken into account. Some of them were considered invasive ones in the reserves because of rather high level of naturalization and spreading in natural and seminatural habitats, others were accepted potentially invasive ones. Fumaria schleicheriSoy.-Will. from this list was not considered because it was definitely native in the Central Altai (Zykova 2015). At the same time some alien species not included in the list were taken into account because they have been naturalized in seminatural and disturbed habitats in the reserves. These are Potentilla norvegica L., Reynoutria sachalinensis (Fr. Schmidt) Nakai, Rumex acetosella L., Rumex crispus L., Sonchus asper (L.) Hill., Xanthoxalis stricta (L.) Small.

Species are divided into groups according to the way of invasion and the level of naturalization. In the first case these are: ergasiophytes - cultivated plants which left places of cultivation; xenophytes - accidentally imported plants. In the second case these are: invasive species (agriophytes) - species that are naturalized and actively spreading in natural and seminatural plant communities (Geltman, 2006); epecophytes - species that are naturalized and actively spreading in disturbed habitats; kolonophytes - species that are naturalized in new habitats but not spreading; ephemerophytes species that appear and disappear from time to time in local habitats.

Conclusions about the naturalization of alien species were made on the basis of field observations, specimens of the Central Siberian Botanical Garden Herbarium (NS) collected by other researchers as well as literature sources (Krylov 1927-1049; Khomutova et al. 1938; Zolotukhin 1983, 1990, 1997, 2012). 


\section{Results}

At present 44 invasive and potentially invasive species occur in the reserves of the Altai Republic (Table1). Among them 23 species were included in the Black Book of the Flora of Siberia (Vinogradova, 2016), 42 species were revealed in the Altaiskiy Reserve and six species were recorded in the Katunskiy Reserve. According to the way of invasion, 30 species are xenophytes and 14 are ergasiophytes. According to the level of naturalization, four species are invasive ones which were registered in the Altaiskiy Reserve: Galinsoga ciliata, Impatiens glandulifera, Rumex acetosella, Strophiostoma sparsiflorum. Other species are potentially invasive, among them are 10 epecophytes, 18 kolonophytes and eight ephemerophytes. Level of naturalization for two species is not defined.

Table1. Invasive and potentially invasive plant species in the Altaiskiy and Katunskiy Reserves of the Altai Republic

\begin{tabular}{|c|c|c|c|c|c|c|c|}
\hline \multirow[t]{2}{*}{ № } & \multirow[t]{2}{*}{ Species name } & \multirow{2}{*}{$\begin{array}{l}\text { Black } \\
\text { Book of } \\
\text { the Flora } \\
\text { of Siberia }\end{array}$} & \multirow{2}{*}{$\begin{array}{l}\text { Way of } \\
\text { invasion }\end{array}$} & \multicolumn{2}{|c|}{ Altaiskiy Reserve } & \multicolumn{2}{|c|}{ Katunskiy Reserve } \\
\hline & & & & $\begin{array}{l}\text { Level of } \\
\text { naturaliza- } \\
\text { tion }\end{array}$ & $\begin{array}{l}\text { Ranger } \\
\text { station }\end{array}$ & $\begin{array}{l}\text { Level of } \\
\text { naturaliza- } \\
\text { tion }\end{array}$ & $\begin{array}{l}\text { Ranger } \\
\text { station }\end{array}$ \\
\hline 1 & Acer negundo L. & + & $\mathrm{Er}$ & $\mathrm{KI}$ & Chi & - & - \\
\hline 2 & Amaranthus retroflexus L. & - & $\mathrm{Xe}$ & Epe & $\begin{array}{l}\text { Be, Chi, } \\
\text { Ya }\end{array}$ & - & - \\
\hline 3 & $\begin{array}{l}\text { Armoracia rusticana (Lam.) Gaertn., } \\
\text { Mey. et Scherb. }\end{array}$ & + & $\mathrm{Er}$ & Epe & $\begin{array}{l}\mathrm{Ba}, \mathrm{Be}, \\
\text { Che, } \\
\text { Chi, Ka, } \\
\text { Ko, Ya }\end{array}$ & - & - \\
\hline 4 & Artemisia absinthium L. & - & $\mathrm{Xe}$ & Eph & $\mathrm{Be}$ & - & - \\
\hline 5 & Bunias orientalis L. & - & $\mathrm{Xe}$ & $\mathrm{KI}$ & $\begin{array}{l}\text { Be, Chi, } \\
\text { Ya }\end{array}$ & - & - \\
\hline 6 & Campanula rapunculoides L. & - & $\mathrm{Er}$ & Eph & Chi, Ya & - & - \\
\hline 7 & Cannabis sativa $\mathrm{L}$. & - & $\mathrm{Xe}$ & $\mathrm{KI}$ & $\mathrm{Be}$ & - & - \\
\hline 8 & Centaurea jacea L. & + & $\mathrm{Xe}$ & $\mathrm{KI}$ & $\mathrm{Ya}$ & - & - \\
\hline 9 & Chenopodium suecicum J. Murray & - & $\mathrm{Xe}$ & Eph & $\mathrm{Ba}$ & - & - \\
\hline 10 & Cirsium vulgare (Savi) Ten. & - & $\mathrm{Xe}$ & $\mathrm{KI}$ & $\mathrm{Ka}, \mathrm{Ya}$ & - & - \\
\hline 11 & Conium maculatum $\mathrm{L}$. & + & $\mathrm{Xe}$ & $\mathrm{KI}$ & Ya & - & - \\
\hline 12 & Conyza canadensis (L.) Cronq. & + & $\mathrm{Xe}$ & $\mathrm{KI}$ & Chi, Ya & - & - \\
\hline 13 & Cuscuta europaea L. & + & $\mathrm{Xe}$ & - & - & Epe & $\mathrm{Ka}$ \\
\hline 14 & C. Iupuliformis Krock. & + & $\mathrm{Xe}$ & $\mathrm{KI}$ & Ya & Epe & Ty, Za \\
\hline 15 & Echinochloa crusgalli(L.) Beauv. & + & $\mathrm{Xe}$ & $\mathrm{KI}$ & $\mathrm{Ya}$ & - & - \\
\hline 16 & $\begin{array}{l}\text { Echinocystis lobata (Michx.) Torr. et } \\
\text { Gray }\end{array}$ & + & $\mathrm{Er}$ & Eph & $\mathrm{Be}, \mathrm{Ya}$ & - & - \\
\hline 17 & Echium vulgare L. & + & $\mathrm{Xe}$ & Eph & $\begin{array}{l}\text { Be, Che, } \\
\text { Chi, Ya }\end{array}$ & - & - \\
\hline 18 & Elsholtzia ciliata (Thunb.) Hyl. & + & $\mathrm{Xe}$ & Epe & $\begin{array}{l}\text { Ba, Be, } \\
\text { Che, } \\
\text { Chi, Ka, } \\
\text { Ko, Ya }\end{array}$ & - & - \\
\hline 19 & Galinsoga ciliata (Rafin.) Blake & - & $\mathrm{Xe}$ & $\ln$ & $\begin{array}{l}\mathrm{Ba}, \mathrm{Be}, \\
\mathrm{Chi}, \mathrm{Ka}, \\
\mathrm{Ya}\end{array}$ & - & - \\
\hline 20 & G. parviflora Cav. & - & $\mathrm{Xe}$ & Eph & $\mathrm{Ba}, \mathrm{Chi}$ & - & - \\
\hline 21 & Galium aparine L. & + & $\mathrm{Xe}$ & - & - & Epe & $\mathrm{Za}$ \\
\hline 22 & Helianthus tuberosus L. & + & $\mathrm{Er}$ & $\mathrm{KI}$ & $\mathrm{Ba}, \mathrm{Ya}$ & - & - \\
\hline 23 & Hordeum jubatum L. & + & $\mathrm{Er}$ & $?$ & $\mathrm{Ka}$ & - & - \\
\hline 24 & Impatiens glandulifera Royle & + & $\mathrm{Er}$ & $\ln$ & $\begin{array}{l}\text { Be, Che, } \\
\text { Ya }\end{array}$ & - & - \\
\hline 25 & $\begin{array}{l}\text { Lepidotheca suaveolens (Pursh) } \\
\text { Nutt. }\end{array}$ & + & $\mathrm{Xe}$ & Epe & $\begin{array}{l}\mathrm{Ba}, \mathrm{Be}, \\
\text { Che, } \\
\text { Chi, Ka, } \\
\text { Ya }\end{array}$ & Epe & $\mathrm{Mu}, \mathrm{Za}$ \\
\hline 26 & Malva mohileviensis Downar & + & $\mathrm{Xe}$ & Epe & $\begin{array}{l}\text { Ba, Be, } \\
\text { Che, } \\
\text { Chi, Ka, } \\
\text { Ko, Ya }\end{array}$ & - & - \\
\hline
\end{tabular}




\begin{tabular}{|c|c|c|c|c|c|c|}
\hline Medicago sativa L. & + & $\mathrm{Er}$ & $\mathrm{KI}$ & Chi & - & - \\
\hline Mentha gracilis Sole & - & $\mathrm{Er}$ & $\mathrm{KI}$ & $\mathrm{Ba}, \mathrm{Ya}$ & - & - \\
\hline Plantago lanceolata L. & + & $\mathrm{Xe}$ & $\mathrm{KI}$ & Ya & - & - \\
\hline Potentilla norvegica L. & - & $\mathrm{Xe}$ & $\mathrm{KI}$ & Ya & $\mathrm{KI}$ & $\mathrm{Mu}, \mathrm{Za}$ \\
\hline P. supina L. & - & $\mathrm{Xe}$ & $\mathrm{KI}$ & $\begin{array}{l}\text { Be, Chi, } \\
\text { Ya }\end{array}$ & - & - \\
\hline $\begin{array}{l}\text { Reynoutria sachalinensis (Fr. } \\
\text { Schmidt) Nakai }\end{array}$ & - & $\mathrm{Er}$ & Epe & $\mathrm{Ka}, \mathrm{Ya}$ & - & - \\
\hline Rumex acetosella $\mathrm{L}$. & - & $\mathrm{Xe}$ & In & $\begin{array}{l}\mathrm{Ba}, \mathrm{Be}, \\
\text { Che, } \\
\text { Chi, Ka, } \\
\mathrm{Ko}, \mathrm{Ya}\end{array}$ & - & - \\
\hline R. crispus L. & - & $\mathrm{Xe}$ & Epe & $\begin{array}{l}\mathrm{Ba}, \mathrm{Be}, \\
\text { Che, } \\
\text { Chi, Ka, } \\
\mathrm{Ko}, \mathrm{Ya}\end{array}$ & - & - \\
\hline Saponaria officinalis L. & + & $\mathrm{Er}$ & $\mathrm{KI}$ & Che, Ya & - & - \\
\hline Setaria viridis P. Beauv. & - & $\mathrm{Xe}$ & Eph & $\mathrm{Ba}, \mathrm{Ya}$ & - & - \\
\hline Solidago canadensis L. & + & $\mathrm{Er}$ & $?$ & $\mathrm{Ba}$ & - & - \\
\hline Sonchus asper (L.) Hill. & - & $\mathrm{Xe}$ & Epe & $\begin{array}{l}\mathrm{Ba}, \mathrm{Be}, \\
\text { Chi, } \mathrm{Ka} \text {, } \\
\mathrm{Ya}\end{array}$ & & \\
\hline S. oleraceus L. & - & $\mathrm{Xe}$ & Eph & Chi, Ka & - & - \\
\hline Sorbaria sorbifolia (L.) A. Br. & - & $\mathrm{Er}$ & $\mathrm{KI}$ & Ya & - & - \\
\hline $\begin{array}{l}\text { Strophiostoma sparsiflorum(Mikan } \\
\text { ex Pohl) Turcz. }\end{array}$ & - & $\mathrm{Xe}$ & In & $\begin{array}{l}\mathrm{Ba}, \mathrm{Ka}, \\
\mathrm{Ko}, \mathrm{Che}, \\
\mathrm{Ya}\end{array}$ & - & - \\
\hline Trifolium hybridum L. & + & $\mathrm{Xe}$ & Epe & $\begin{array}{l}\mathrm{Ba}, \mathrm{Be}, \\
\text { Che, } \\
\text { Chi, Ka, } \\
\mathrm{Ko}, \mathrm{Ya}\end{array}$ & $\mathrm{KI}$ & $\mathrm{Za}$ \\
\hline $\begin{array}{l}\text { Tripleurospermum inodorum (L.) } \\
\text { Sch. Bip. }\end{array}$ & + & $\mathrm{Xe}$ & $\mathrm{KI}$ & $\begin{array}{l}\text { Che, Ka, } \\
\text { Ya }\end{array}$ & - & - \\
\hline Xanthoxalis stricta (L.) Small & - & $\mathrm{Er}$ & Epe & $\begin{array}{l}\text { Ba, Be, } \\
\text { Che, } \\
\text { Chi, Ka, } \\
\text { Ko, Ya }\end{array}$ & - & - \\
\hline
\end{tabular}

Way of invasion: Er - ergasiophyte, Xe - xenophyte. Level of naturalization: In - invasive species (agriophyte), Epe - epecophyte; KI kolonophyte, Eph - ephemerophyte, ? - level of naturalization is not defined.

Village and ranger stations of the Altaiskiy reserve: Ba - Baygazan, Be - Bele, Che - Chelyush, Chi - Chiri, Ka - Karatash, Ko - Kokshi, Ya Yaylyu.

Ranger stations of the Katunskiy reserve: Ka - Kazinikha River, Mu - Lake Srednee Mul'tinskoe, Ty - Tyurgen' River, Za - Zaychikha River.

\section{Discussion}

Invasive and potentially invasive species of the Altaiskiy Reserve were registered in Yaylyu village and in the ranger stations situated in vicinity of Lake Teletskoye where climate is relatively soft. Most of the species were found in Yaylyu village, which has transport communication with settlements outside the reserve.

Four alien species recorded in the Altaiskiy Reserve are invasive. They form dense single species growths into natural and seminatural habitats or dominate / subdominate in plant communities. Rumex acetosella was first registered in the reserve in the middle of XX century (Kuminova 1960) and by 1980s became one of the most common and abundant species on pastures and hayfields (Zolotukhin 1983). Galinsoga ciliata and Strophiostoma sparsiflorum were imported in the reserve at the end of XX century (Zolotukhin 1990, 1997, 2012). By present, they made weeds difficult to eradicate, which are actively spreading in vegetable gardens, cattle yards, pastures and hayfields (Fig. 4). In the last years, Impatiens g/andulifera left places of cultivation and formed growths at ravines and stream banks. 


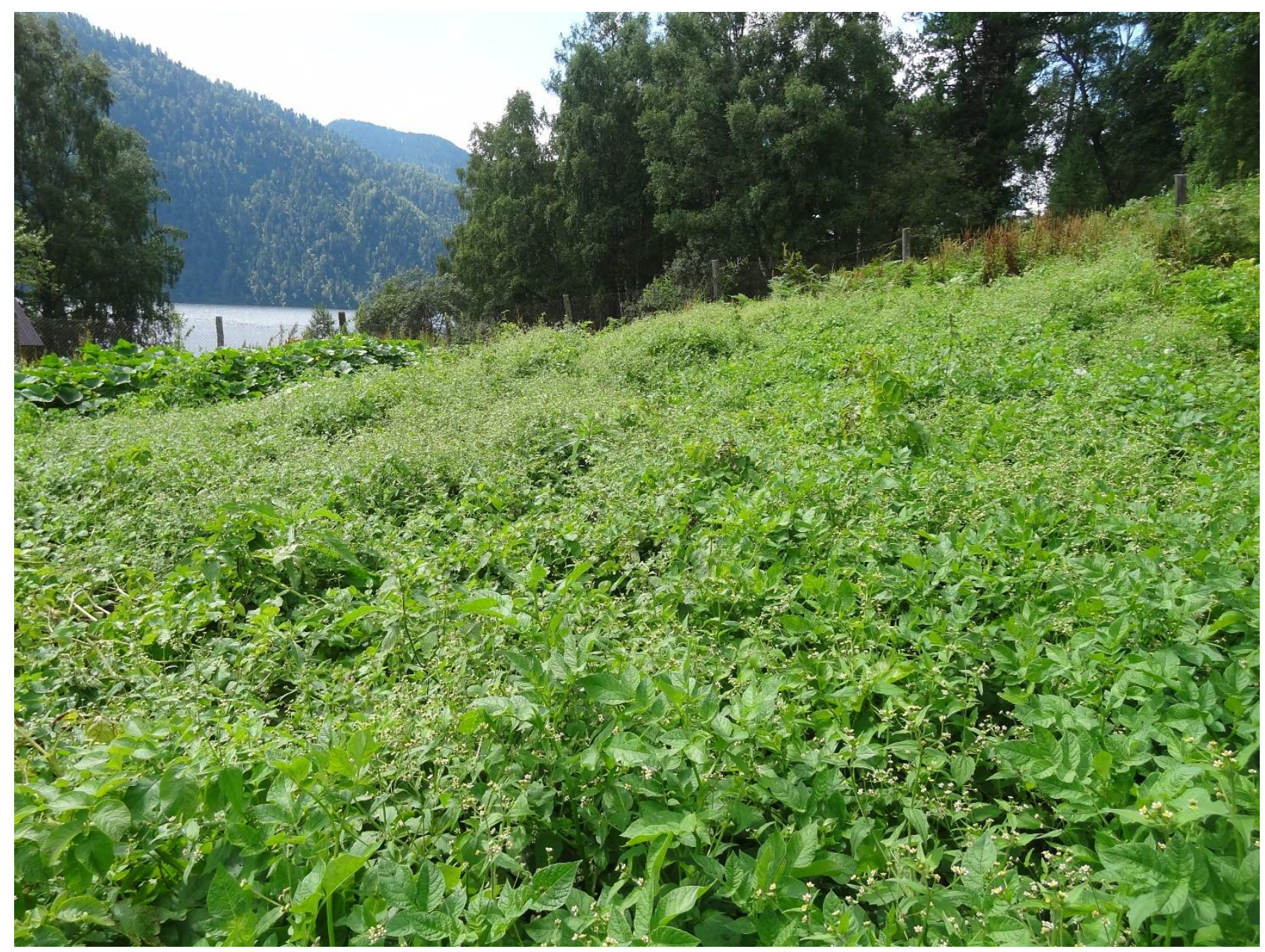

Fig. 4. Galinsoga ciliata near the Chelyush ranger station in the Altaiskiy Reserve.

Most of the invasive and potentially invasive species of the reserve occur around houses. These are cultivated food and ornamental plants which easily leave places of cultivation: Armoracia rusticana, Impatiens glandulifera, Reynoutria sachalinensis, Xanthoxalis stricta (Fig. 5), as well as garden weeds: Galinsoga ciliata, Malva mohileviensis, Strophiostoma sparsiflorum. Other species are common on cattle yards, by the roadsides and on wasting lands: Lepidotheca suaveolens, Rumex crispus, Sonchus asper, Trifolium hybridum.

Some species had obviously arrived before the establishment of the Altaiskiy Reserve. These are Amaranthus retroflexus, Elsholtzia ciliata and Lepidotheca suaveolens which in 1930s were noted near Yaylyu village (Khomutova et. al., 1938).

The revealed invasive and potentially invasive species most likely appeared in the Altaiskiy Reserve as a result of activity of the reserve itself rather than because of tourism and recreation use of its territory. For example, in 1960s Reynoutria sachalinensis was planted in a nursery near Yaylyu village (Zolotukhin, 1983). Since that time it spread and now appears near houses, at banks and ravines. Hordeum jubatum and Solidago canadensis should be mentioned as new immigrants. These dangerous invasive species were recorded at Karatash and Baygazan ranger stations where they had been planted as ornamental plants. Taking into account reproduction potential and high dispersal ability of these species, their rapid spreading should be expected in the lakeside part of the reserve. On the other hand, invasive and potentially invasive species were not found near the Korbu Waterfall although it is the most popular and visited place of the reserve.

The number of invasive and potentially invasive species revealed in the Katunskiy Reserve is substantially less than in the Altaiskiy Reserve. Most of them were recorded in the vicinity of the ranger stations in the southern part of the Katunskiy Reserve, in the valley of the Katun' River near the mouths of its right tributaries Zaychikha and Tyurgen', at elevations from 1300 to 1800 m a.s.I.: Cuscuta lupuliformis, Galium aparine, Lepidotheca suaveolens, Trifolium hybridum. Before the dissolution of the USSR and the establishment of the reserve, these territories were rather intensively used as pastures and for timber harvesting by collective farms from Kazakhstan. Wood bridges across which cattle and transport passed were built over the Katun' and Zaychikha Rivers, a country road was made in the Katun' valley, a sawmill worked in the mouth of Zaychikha River. Such activities were undoubtedly accompanied with the invasion of alien species. At present the Katun' valley in its upper reaches is under protection of border guards and reserve rangers. The bridges were destroyed, the roads were owergrown. Therefore the possibility of invasion of new alien species as well as secondary invasions into the southern part of the Katunskiy Reserve is minimal. 


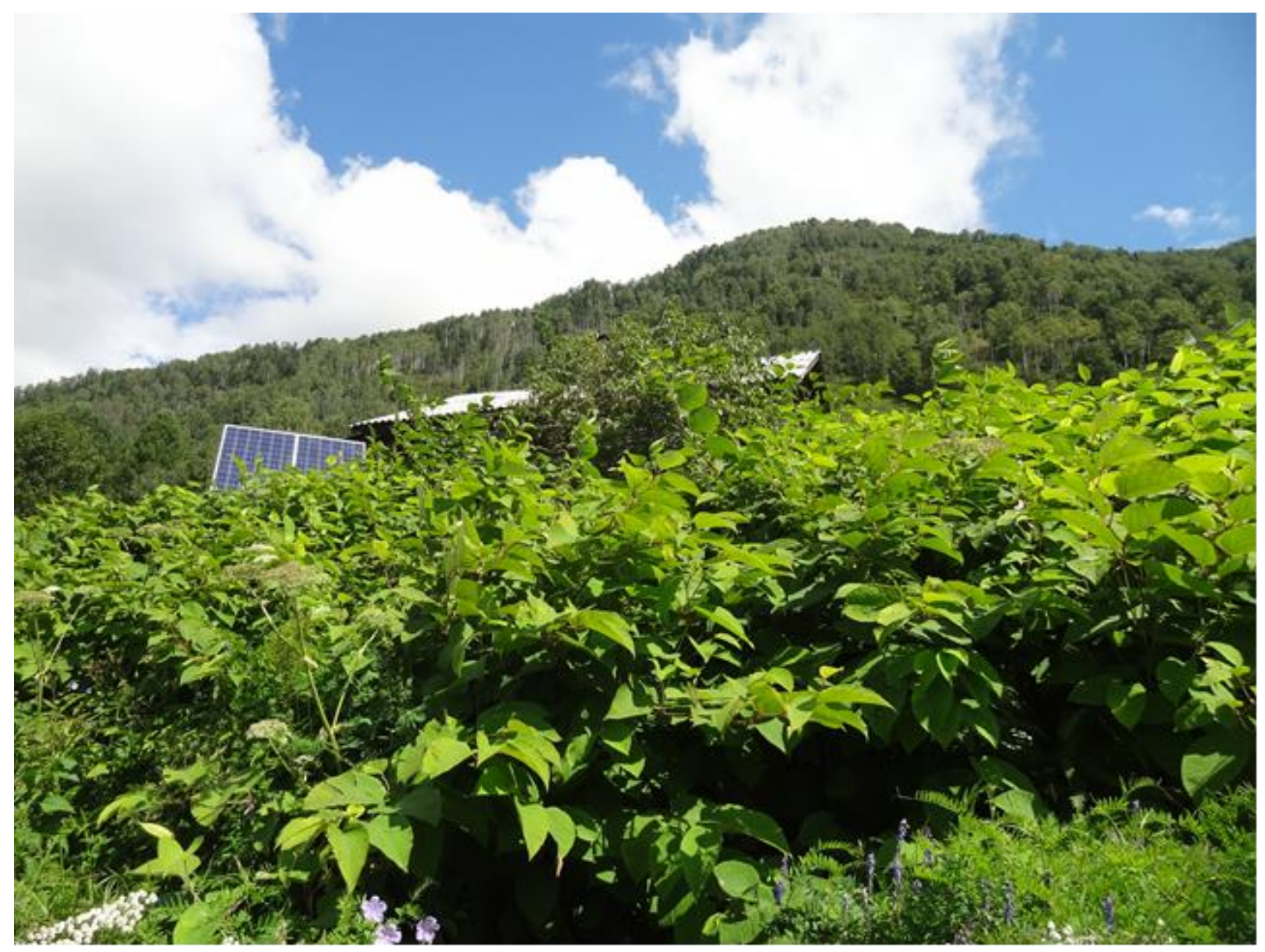

Fig. 5. Reynoutria sachalinensis near the Karatash ranger station in the Altaiskiy Reserve.

Oppositely, the northern part of the Katunskiy Reserve is undergoing recreation pressure. In its protection zone there is a tourist base situated near the northern end of Lake Nizhnee Mul'tinskoe, as well as a ranger station and a tourist camp located near the southern end of Lake Srednee Mul'tinskoe. From there visitors take one day hiking routes to the core zone of the reserve, to Lakes Verkhnee Mul'tinskoe and Poperechnoe. From 1500 to 2000 people walk along these ecology trails per year. In spite of such rather substantial recreation pressure, only two naturalized potentially alien species were registered on the territories of the ranger station, tourist base and camp. These are Lepidotheca suaveolens and Potentilla norvegica which are not seldom on degraded low grass meadows and in weed plant communities. It worth to note that Potentilla norvegica was observed as in the lower part of the buffer zone near car parking (1677 m a.s.l) as well as rather high in the core zone in tundra community (2120 m a.s.l.), on the way of tourists which are going to the mountain pass. And if in the first case plants were $20 \mathrm{~cm}$ tall, in the second case it was one plant $2 \mathrm{~cm}$ tall. This suggest that the obstacle of spreading of this species in the core zone of the reserve is not the absence of dispersal agents, but severe conditions in high mountains.

Most of invasive and potentially invasive species in the reserves of the Altai Republic were registerded in the parts of the reserves where the climate is relatively soft. In the Altaiskiy Reserve it is the lakeside part which is characterized by snowy winters, warm and rainy summers; in the Katunskiy Reserve it is the south-western low mountain part in the the Katun' River valley and near the mouths of its tributaries.

Appearance of invasive and potentially invasive species in the reserves was caused mainly by human activity before the reserves establishment as well as activity of the reserves themselves in Yaylyu village and ranger stations, in particular, due to exploitation of small areas as vegetable gardens, pastures and hayfields.

A substantial number of invasive and potentially invasive species in the reserves occur in artificial and disturbed habitats in Yaylyu village and at the ranger stations, in the nearest pastures and hayfields. Some species grow on the pebble banks of Lake Teletskoye.

In spite of big number of visitors in the reserves, alien invasive and potentially invasive species are virtually absent on the ecological paths while apophytes spread in tourist camps and along tourist and the ecological paths.

Taking into account that the principal parts of the reserves of the Altai Republic are occupied by high mountain landscapes characterized by severe climate and undisturbed vegetation cover, it is possible to conclude that the invasive and potentially invasive species arrived in the reserves due to recreation and other activity are not a threat to biodiversity 
of the reserves. At the same time, monitoring of invasive plants for prevention of casual or intentional invasions is necessary, first of all in Yaylyu village and at the ranger stations.

\section{Acknowledgements}

The research was partly supported by RFFI (16-04-01246_A). Materials of the bioresource scientific collection of the Central Siberian Botanical Garden SB RAS "Herbarium of vascular plants, lichens and fungi (NS, NSK)" (UNU № USU 440537) were used.

\section{References}

Alimov AF, Bogutskaya NG. 2004. Biological invasions in aquatic and terrestrial ecosystems. Moscow, Russia: KMK Scientific Press Publ.

Allen JA, Brown CS, Stohlgren TJ. 2009. Non-native plant invasions of United States National Parks. Biological Invasions 11: 2195-2207. doi:10.1007/s10530-008-9376-1

Altaiskiy State Nature Biosphere Reserve. (n.d.). Retrieved from http://www.altzapovednik.ru/en/welcome.aspx

Artemov IA. 2012. Plant identification guide of the Katunskiy Biosphere Reserve. Barnaul, Russia: Pyat'-Plyus.

Artemov IA, Baylagasov LV, Bocharova EN, Diev EYu, Pal'tsyn MYu. 2000. Katunskiy Reserve. In: Pavlov DS, Sokolov VE, Syroechkovskiy EE, editors. Reserves of Siberia, 2. Moscow, Russia: LOGATA. p. 122-128,

Early R, Bradley BA, Dukes JS, Lawler JJ, Olden JD, Blumenthal DM, Gonzalez P, Grosholz ED, Ibañez I, Miller LP et al. 2016. Global threats from invasive alien species in the twenty-first century and national response capacities. Nature Communications 7, 12485. doi: $10.1038 /$ ncomms12485

Ebel AL, Strelnikova TO, Kupriyanov AN, Anenkhonov OA, Ankipovich ES, Antipova EM, Verkhozina AV, Efremov AN, Zykova EYu, Mikhaylova SI et al. 2014. Invasive and potentially invasive species in Siberia. Bulletin Main Botanical Garden 200(1): 52-61.

Foxcroft LC, Pyšek P, Richardson DM, Genovesi P, MacFadyen S. 2017. Plant invasion science in protected areas: progress and priorities. Biological Invasions 19: 1353-1378. doi: 10.1007/s10530-016-1367-z

Geltman DV. 2006. On the term "invasive species" as applied to the vascular plants. Botanicheskii Zhurnal, 91(8), 1222-1231.

Katun Nature Reserve. (n.d.). [accessed November 2, 2019]. http://www.katunskiy.ru/en

Khomutova MS, Zolotovskiy MV, Goncharova AN. 1938. Checklist of plants of the Altaiskiy State Reserve. Proceedings of the Altaiskiy State Reserve 2: 139-247.

Krever VG. (Ed.). 2012. Specially Protected Nature Areas of the Altai Republic. Current state and development prospects. Krasnoyarsk, Russia: Gorod Publ.

Krylov PN. 1927-1949. Flora of Western Siberia, 1-11. Tomsk, Russia.

Kuminova AV. 1960. Vegetation of the Altai. Novosibirsk, Russia: Siberian Branch of Academy of Sciences of USSR Publ.

Maleshin NA, Zolotukhin NA, Yakovleva VA, Sobanskiy GG, Staheev VA., Syroechkovskiy EE, Rogacheva EV. 1999. Altaiskiy Reserve. In: Pavlov DS, Sokolov VE, Syroechkovskiy EE, editors. Reserves of Siberia, 1. Moscow: LOGATA. p. 58-72.

Monaco A, \& Genovesi P. 2014. European Guidelines on Protected Areas and Invasive Alien Species. Council of Europe, Strasbourg, Regional Parks Agency - Lazio Region, Rome, Italy.

Nukhimovskaya YuD. 1986. Synanthropic element in the floras of reserves of the USSR. In: Sokolov VE, editor. Results and prospects of nature conservation in the USSR. Moscow: Nauka. p. 153-172

Olmstead RG. 2006. Are invasive plants an inevitable consequence of evolution? American Journal of Botany 93(8): 12361239. doi:10.3732/ajb.93.8.1236

Olson DM, Dinerstein E. 2002. The Global 200: priority ecoregions for global conservation. Annals of the Missouri Botanical Garden 89: 199-224. doi: $10.2307 / 3298564$

Pyšek P, Jarošík V, \& Kučera T. 2002. Patterns of invasion in temperate nature reserves. Biological Conservation 104: $13-24$. doi: 10.1016/S0006-3207(01)00150-1

Pyšek P, Pergl J, Essl F, Lenzner B, Dawson W, Kreft H, Weigelt P, Winter M, Kartesz J, Nishino M et al. 2017. Naturalized alien flora of the world: species diversity, taxonomic and phylogenetic patterns, geographic distribution and global hotspots of plant invasion. Preslia 89: 203-274. doi: 10.23855/preslia.2017.203

Medvedeva MV. 2018. Impact of economic activity on the environment. In Report on the state and protection of the environment of the Altai Republic in 2017. Russia: Gorno-Altaisk. (In Russian).

Starodubtseva EA, Grigoryevskaya AYa, Lepeshkina LA, Lisova OS. 2017. Alien species in local floras of the Voronezh region nature reserve fund (Russia). Nature Conservation Research 2(4): 53-77. doi:10.24189/ncr.2017.041

Tittensor DP, Walpole M, Hill SL, Boyce DG, Britten GL, Burgess ND, Butchart SH, Leadley PW, Regan EC, Alkemade R et al. 2014. A mid-term analysis of progress toward international biodiversity targets. Science 346: 241-244. doi:10.1126/science.1257484

van Kleunen M, Dawson W, Essl F, Pergl J, Winter M, Weber E, Kreft H, Weigelt P, Kartesz J, Nishino M et al. 2015. Global exchange and accumulation of non-native plants. Nature 525(7567): 100-3. doi:10.1038/nature14910 
van Kleunen M, Pyšek P, Dawson W, Essl F, Kreft H, Pergl J, Weigelt P, Stein A, Dullinger S, König C et al. 2019. The Global Naturalized Alien Flora (GloNAF) database. Ecology, 100(1), e02542. doi:10.1002/ecy.2542

Vinogradova YuK. (Ed.). 2016. Black Book of the Flora of Siberia. Novosibirsk, Russia: Academic Publishing House “GEO”. (In Russian)

Williamson M. 1996. Biological Invasions. London, UK: Chapman and Hall.

Zolotukhin NI. 1983. Alien plants in the Altai reserve. Botanicheskii Zhurnal 68(11): 1528-1533.

Zolotukhin NI. 1990. Multiyear dynamic of the alien flora in village Yaylyu and ranger stations of the Altaiskiy Reserve. In Anthropogenic impact to the nature of reserves: Proceedings of CSRL of Glavokhoty RSFSR (pp. 107-118). Moscow, Russia.

Zolotukhin NI. 1997. New data on dynamic of the alien flora in the Altaiskiy Reserve. In: Multiyear dynamic of nature processes and biological divercity of the protected ecosystems of the Central Chernosem region and the Altai. Proceedings of the Tsentralno-Chernozemny state reserve 15: 181-187.

Zolotukhin NI. 2012. Florictic records in the Altai Republic. Bulletin of Moscow society of naturalists. Biological series 117(3): 77-80.

Zykova EYu. 2015. Alien flora of the Altai Republic. Rastitel'nyj Mir Aziatskoj Rossii 19(3): 72-87.

Zykova EYu. 2016. Invasive species in the flora of the Altai Republic. In Conservation of plant diversity in botanical gardens: traditions, modernity, prospects: Materials of the International Conference dedicated to the $70^{\text {th }}$ anniversary of the CSBG (Novosibirsk, 1-8 August, 2016) (pp. 115-116). Novosibirsk, Russia.

\section{Citation:}

Artemov IA, Zykova EYu. 2019. Invasive and potentially invasive plant species in State Nature Biosphere Reserves of the Altai Republic (Russia). Acta Biologica Sibirica 5(4): 73-82.

Submitted: 12.10.2019. Accepted: 12.12.2019

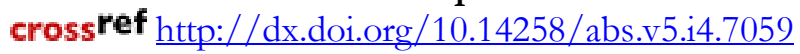

(C) 2019 by the authors. Submitted for possible open access publication under the terms and conditions of the Creative Commons Attribution (CC BY) license (http://creativecommons.org/licenses/by/4.0/). 